ISSN 1112-9867

Available online at

http://www.jfas.info

\title{
CONSUMPTION OF AMMONIA-NITROGEN BY AOB IN IMMOBILIZED BATCH CULTURE
}

\author{
N. Kasmuri ${ }^{1, *}$, R. W. Lovitt ${ }^{2}$ and M. Omar ${ }^{3}$ \\ ${ }^{1}$ Faculty of Civil Engineering, UniversitiTeknologi MARA, Shah Alam, Selangor, Malaysia \\ ${ }^{2}$ College of Engineering, Swansea University, Singleton Park, Swansea, United Kingdom \\ ${ }^{3}$ Academy of Language Studies, UniversitiTeknologi MARA, Shah Alam, Selangor, Malaysia
}

Published online: 10 November 2017

\begin{abstract}
This study investigated the performance of bio-filters immobilized nitrifying bacteria, ammonia oxidizing bacteria (AOB) and nitrite oxidizing bacteria (NOB). In particular, it was to assess the consumption of ammonia-nitrogen $\left(\mathrm{NH}_{3}-\mathrm{N}\right)$ by the AOB. The experiment was conducted in a one litre reactor. The reactor consisted of bio-filters with $\mathrm{NH}_{3}-\mathrm{N}$ as the substrate for the nitrifying bacteria.Low concentration of $\mathrm{NH}_{3}-\mathrm{N}$ (between 5 and $25 \mathrm{mg} / \mathrm{L}$ ) and high concentrations (between 35 and $100 \mathrm{mg} / \mathrm{L}$ ) were used in this batch culture experiment.Simultaneously, the production of nitrate-nitrogen was also evaluated by the consumption of nitrite-nitrogen by the NOB.The results showed that the nitrifying bacteria in the bio-filters were able to reduce the $\mathrm{NH}_{3}-\mathrm{N}$ rapidly between 5 and $15 \mathrm{mg} / \mathrm{L}$ of $\mathrm{NH}_{3}-\mathrm{N}$.It was also found that the highest removal rate of $\mathrm{NH}_{3}-\mathrm{N}$ was in $100 \mathrm{mg} / \mathrm{L}$.
\end{abstract}

Keywords: ammonia-nitrogen; immobilized; bio-filter; batch culture.

Author Correspondence, e-mail: norhafezahkasmuri@salam.uitm.edu.my doi: http://dx.doi.org/10.4314/jfas.v9i6s.21 


\section{INTRODUCTION}

Recent concerns on the existence of nitrogen in the forms of ammonia and nitrate has brought a significant impact on the quality of surface water. The existence of nitrogen in water has increased due to the rapidly growing population [1]. The ammonia-nitrogen in the water leads to poor water quality which will harm aquatic organisms especially fish [2]. Hence, a stringent water quality standard has been introduced in developed countries, especially in the United Kingdom [3] to limit the existence of pollutants in the river. However, the high cost of treatments to improve water quality remains a major challenge [4].

In search of a cost effective treatment, the attached growth system using bio-filter has been attempted and known to have been suitable for sustainable water management [5]. The reduction of ammonia-nitrogen to nitrite-nitrogen and nitrate-nitrogen (nitrification) by biological degradation process of nitrifying bacteria (AOB and NOB) can be determined using bio-filter [1]. Hence, this research investigated the use of different ammonia-nitrogen concentrations to identify the removal rate of ammonia-nitrogen in an attached growth system (or a bio-filter).

It is commonly known that the oxidation of ammonia-nitrogen and nitrite-nitrogen are performed by Nitrosomonas species and Nitrobacter species. Nevertheless, there are also other types of nitrifying bacteria in the fish effluent, i.e. ammonia oxidizing organisms which can consume the ammonia-nitrogen [1].

\section{MATERIALS AND METHOD}

\subsection{Chemicals and Materials}

The AOB and NOB used in this study was collected from the fish effluents provided by the Centre for Sustainable Aquatic Research, College of Science, Swansea University. The chemicals were purchased from Sigma Aldrich Co. Ltd, the United Kingdom.

\subsection{Design of Batch Culture}

The batch experiments were performed to assess ammonia-nitrogen concentrations and the effects of nitrifying bacteria using fish effluent culture as the substrate. There is consensus that ammonia oxidation by groups of nitrifying bacteria is to follow Michaelis-Menten kinetics [6-7]. The ammonia-nitrogen concentrations up to $100 \mathrm{mg} / \mathrm{L}$ ammonia-nitrogen were 
used, and assays were conducted at $30^{\circ} \mathrm{C}$ in an incubator. It was performed at the optimum $\mathrm{pH}$ 8 with a dosing of sodium hydroxide $(\mathrm{NaOH})$ and/or hydrochloric acid $(\mathrm{HCl})$. The choice of temperature and $\mathrm{pH}$ were made according to [8]. The K2 AnoxKaldnes bio-filter was selected to be the most suitable bio-filter in a batch culture.

A one litre culture bottle was employed as the reactor of the batch culture. It contained one litre of nitrification medium shown in Table 1 [1]. The medium had been autoclaved for fifteen minutes. Then it was added to the reactor with $100 \mathrm{~mL}$ of an enrichment culture of fish effluent following the [1], serial batch reaction. The reactor was aerated through a pumice stone using an aeration pump connected by a silicone tubing through a hole made on the top of the cap of the reactor. The dissolved oxygen was closely monitored with a dissolved oxygen probe on a daily basis so that the dissolved oxygen in the reactor was maintained above $6 \mathrm{mg} / \mathrm{L}$.

Table 1.Nitrification medium

\begin{tabular}{cc}
\hline Formulation & Weight (g) \\
\hline $\mathrm{Na}_{2} \mathrm{HPO}_{4}$ & 13.5 \\
$\mathrm{KH}_{2} \mathrm{PO}_{4}$ & 0.7 \\
$\mathrm{NaHCO}_{3}$ & 0.5 \\
$\mathrm{MgSO}_{4} \cdot 7 \mathrm{H}_{2} \mathrm{O}$ & 0.1 \\
$\mathrm{FeCl}_{3} \cdot 6 \mathrm{H}_{2} \mathrm{O}$ & 0.014 \\
$\mathrm{CaCl}_{2} .2 \mathrm{H}_{2} \mathrm{O}$, & 0.18 \\
\hline
\end{tabular}

The dissolved oxygen (DO) has to be relatively high as this is the limiting factor in biofilm processes and in an immobilized reactor system [9]. A high driving force in the form of DO concentration across the biofilm is therefore required. Typically, for an immobilized system of moving particles with a suspended carrier, the operation of the system demands a high DO concentration which is between $5-7 \mathrm{mg} / \mathrm{L}$ [10]. The conditions regarding the oxygen transfer rate for an immobilized system with moving suspended particles is similar to those achieved in conventional aeration tanks by fine bubble aeration, although coarse bubble aeration can be used in an immobilized system with moving suspended particles. On the other hand, the biofilm on thebio-filter becomes thinner at higher loading rates because of the mixing intensity in aerated or stirred tanks compared to attached growth systems using 
trickling filters or rotating biological contactors [9]. The bottles were capped to prevent spillage of the medium and to ensure that the aeration in the reactor containing the $\mathrm{K} 2$ AnoxKaldnes bio-filter provided a constant motion of the bio-filter in the submerged stage. The experiments in one litre reactors were operated for more than two weeks. Fig. 1 shows a diagram of the batch culture using K2 AnoxKaldnes bio-filter in the reactor.



Fig.1.Batch culture

\subsection{Instrument}

The levels of ammonia-nitrogen, nitrite-nitrogen and nitrate-nitrogen were determined on a daily basis. The $\mathrm{pH}$ was monitored using a $\mathrm{pH}$ probe and the chemical oxygen demand was determined by the standard methods[11].

\section{RESULTS AND DISCUSSION}

Two stages of the experiments were conducted to assess the effect of different substrate concentrations on ammonia oxidation using a moving bed batch reactor with nitrifying bacteria on the K2 AnoxKaldnes bio-filter. Stage 1 involved low concentrations of ammonia-nitrogen which were between $5 \mathrm{mg} / \mathrm{L}$ to $25 \mathrm{mg} / \mathrm{L}$, while Stage 2 involved higher concentrations between $35 \mathrm{mg} / \mathrm{L}$ and $100 \mathrm{mg} / \mathrm{L}$. 


\subsection{Low Substrate Concentration of Ammonia-Nitrogen $(5-25 \mathrm{mg} / \mathrm{L})$}

Fig. 2 shows the occurrence of the nitrification process in the three concentrations of ammonia-nitrogen. The ammonia-nitrogen was found to have decreased rapidly within a short incubation period while the nitrate-nitrogen increased in the concentrations of $5 \mathrm{mg} / \mathrm{L}$ and 15 $\mathrm{mg} / \mathrm{L}$ ammonia-nitrogen respectively. On the hand, the ammonia oxidation required a longer incubation period of nearly 12 days to complete the nitrification process in $25 \mathrm{mg} / \mathrm{L}$ ammonia-nitrogen.

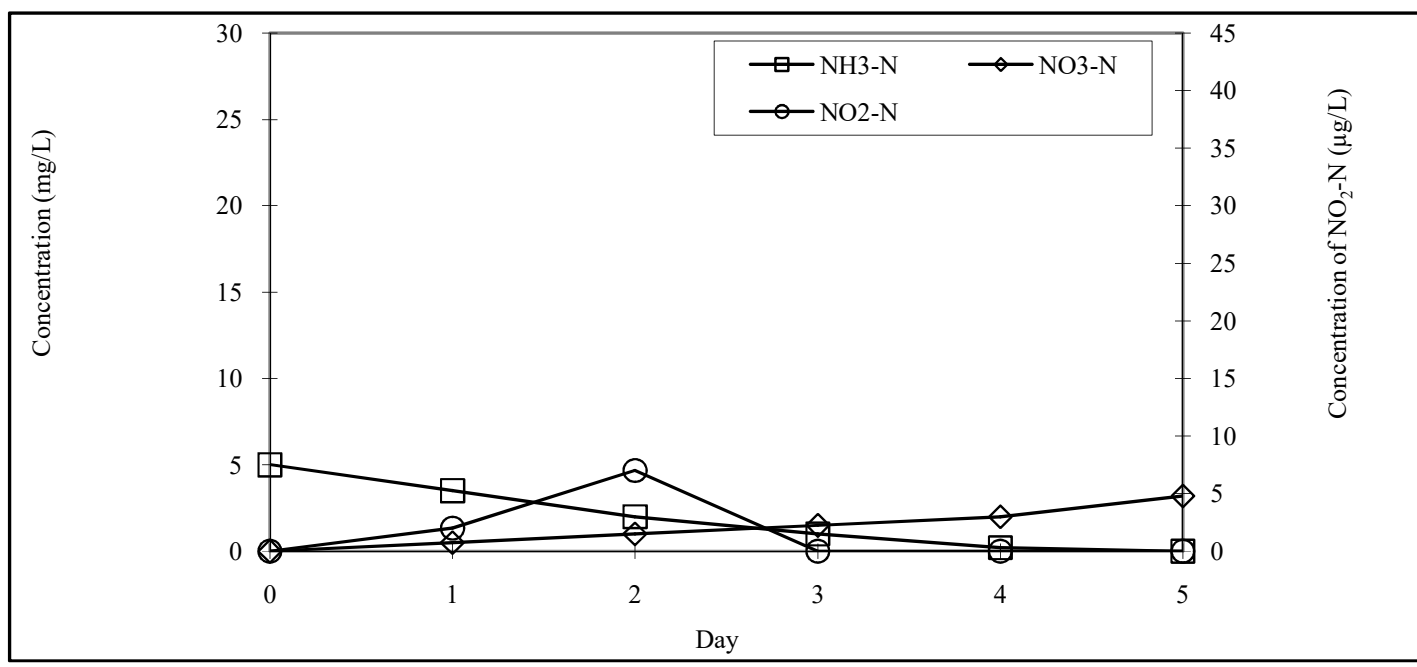

Fig.2A. The effect of $5 \mathrm{mg} / \mathrm{L}$ on nitrification in batch reactor experiments using the $\mathrm{K} 2$

AnoxKaldnes bio-filter

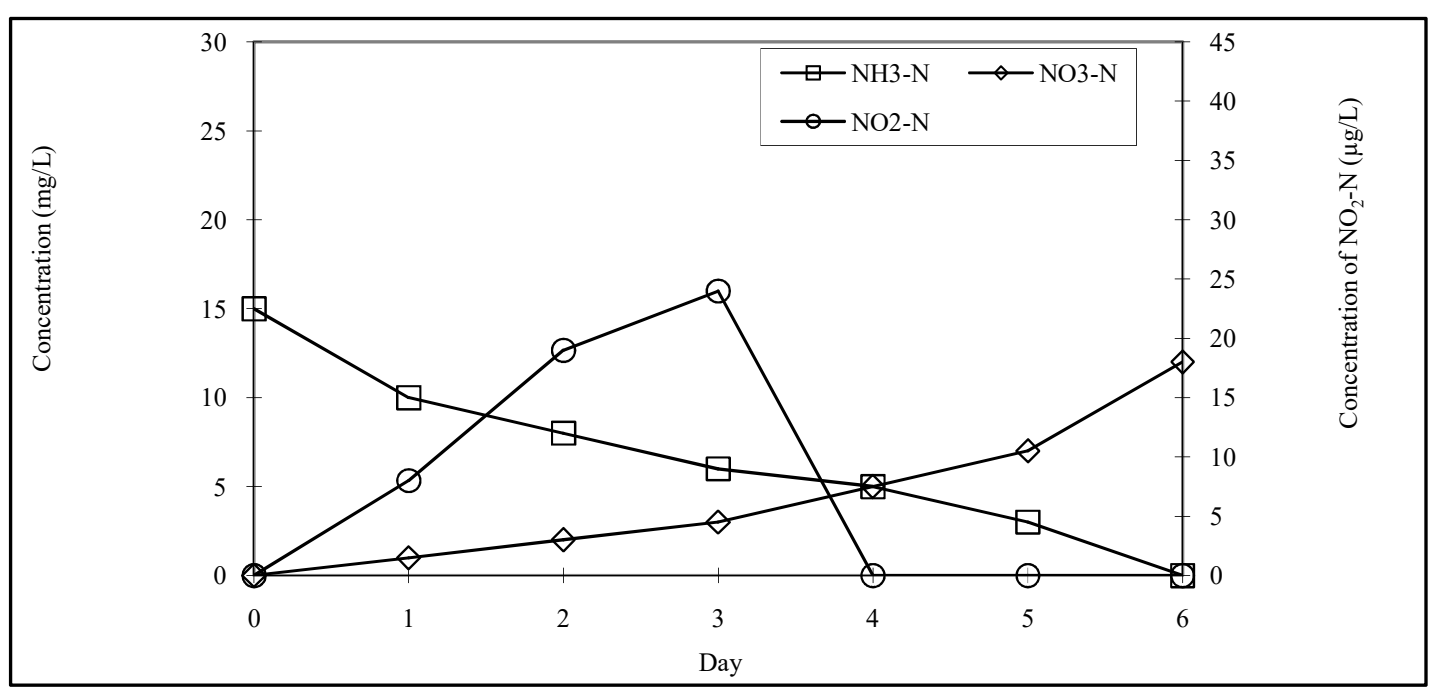

Fig.2B. The effect of $15 \mathrm{mg} / \mathrm{L}$ on nitrification in batch reactor experiments using the $\mathrm{K} 2$ AnoxKaldnes bio-filter 




Fig.2C. The effect of $25 \mathrm{mg} / \mathrm{L}$ on nitrification in batch reactor experiments using the $\mathrm{K} 2$

AnoxKaldnes bio-filter

\subsection{High Substrate Concentration of Ammonia-nitrogen (35-100 mg/L)}

Fig. 3A and 3B show the concentrations of nitrate-nitrogen increasing steadily at $35 \mathrm{mg} / \mathrm{L}$ ammonia-nitrogen and $65 \mathrm{mg} / \mathrm{L}$ ammonia-nitrogen (as the ammonia oxidiser bacteria consumed the ammonia-nitrogen). The amounts of nitrite-nitrogen of all concentrations decline sharply as the nitrate-nitrogen increases. This condition is presumed to be caused by the nitrite oxidisers converting the nitrite-nitrogen to nitrate-nitrogen. Fig. 3D shows a high amount of nitrite-nitrogen, $100 \mathrm{mg} / \mathrm{L}$ of ammonia-nitrogen concentration which is nearly 950 $\mu \mathrm{g} / \mathrm{L}$ nitrite-nitrogen on Day 3. However, this decreases rapidly by Day 5 to almost zero by the end of the incubation period. 


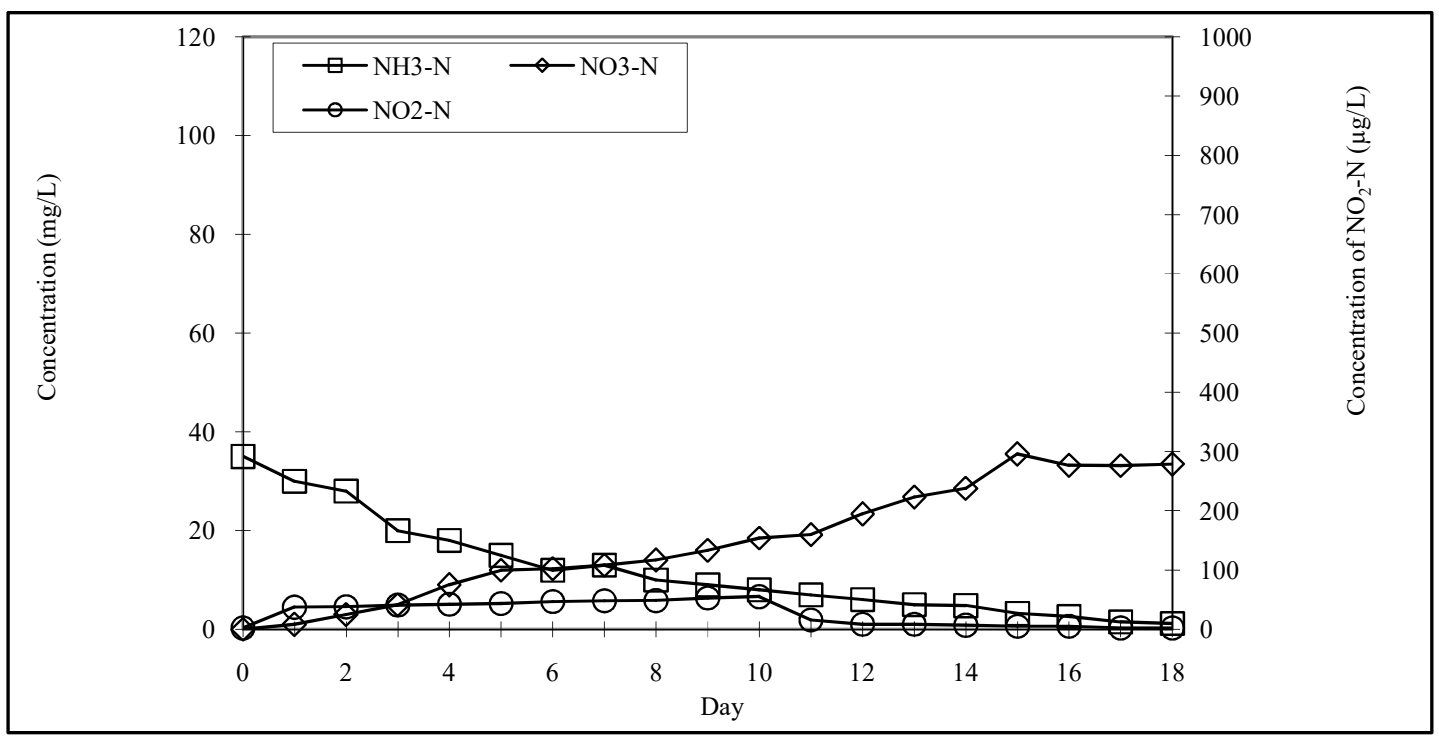

Fig.3A. The effect of $35 \mathrm{mg} / \mathrm{L}$ on nitrification in batch reactor experiments using the $\mathrm{K} 2$

AnoxKaldnes bio-filter



Fig.3B. The effect of $65 \mathrm{mg} / \mathrm{L}$ on nitrification in batch reactor experiments using the $\mathrm{K} 2$ AnoxKaldnes bio-filter 


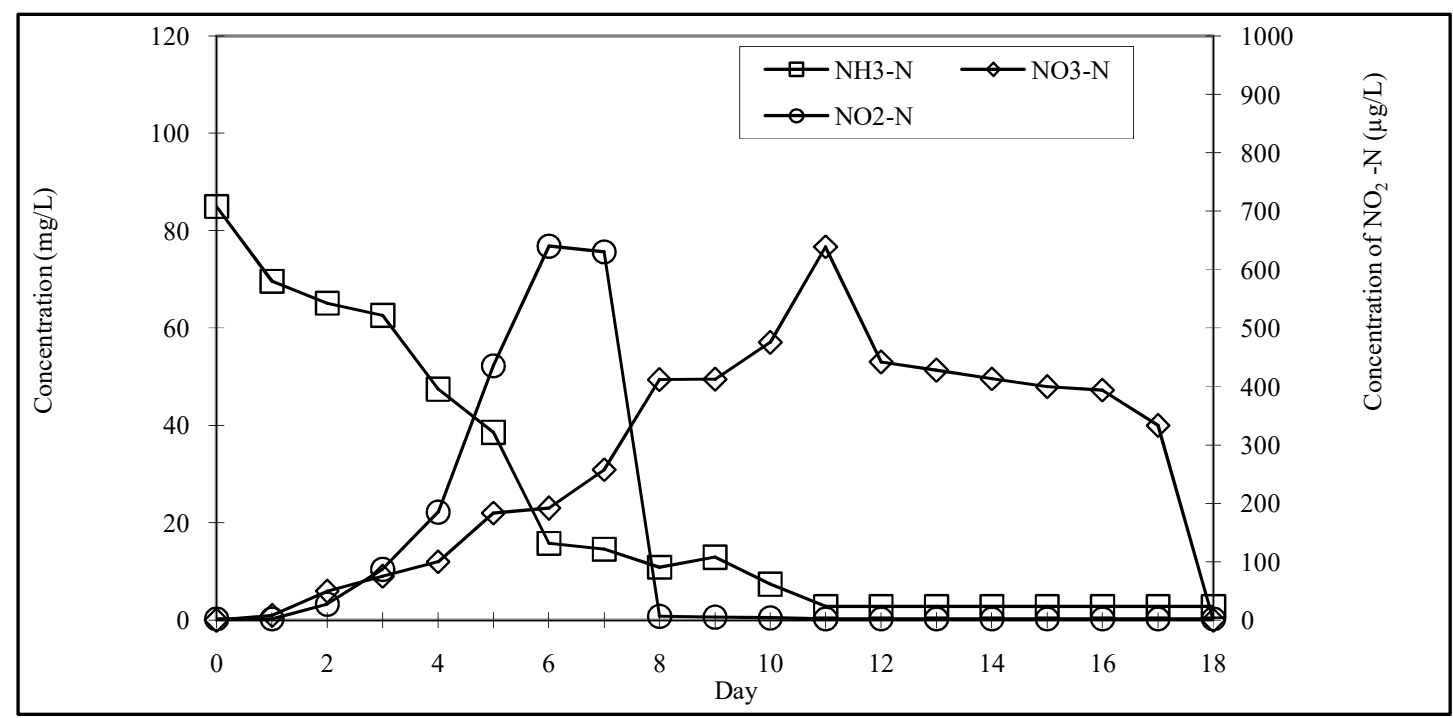

Fig.3C. The effect of $85 \mathrm{mg} / \mathrm{L}$ on nitrification in batch reactor experiments using the $\mathrm{K} 2$ AnoxKaldnes bio-filter

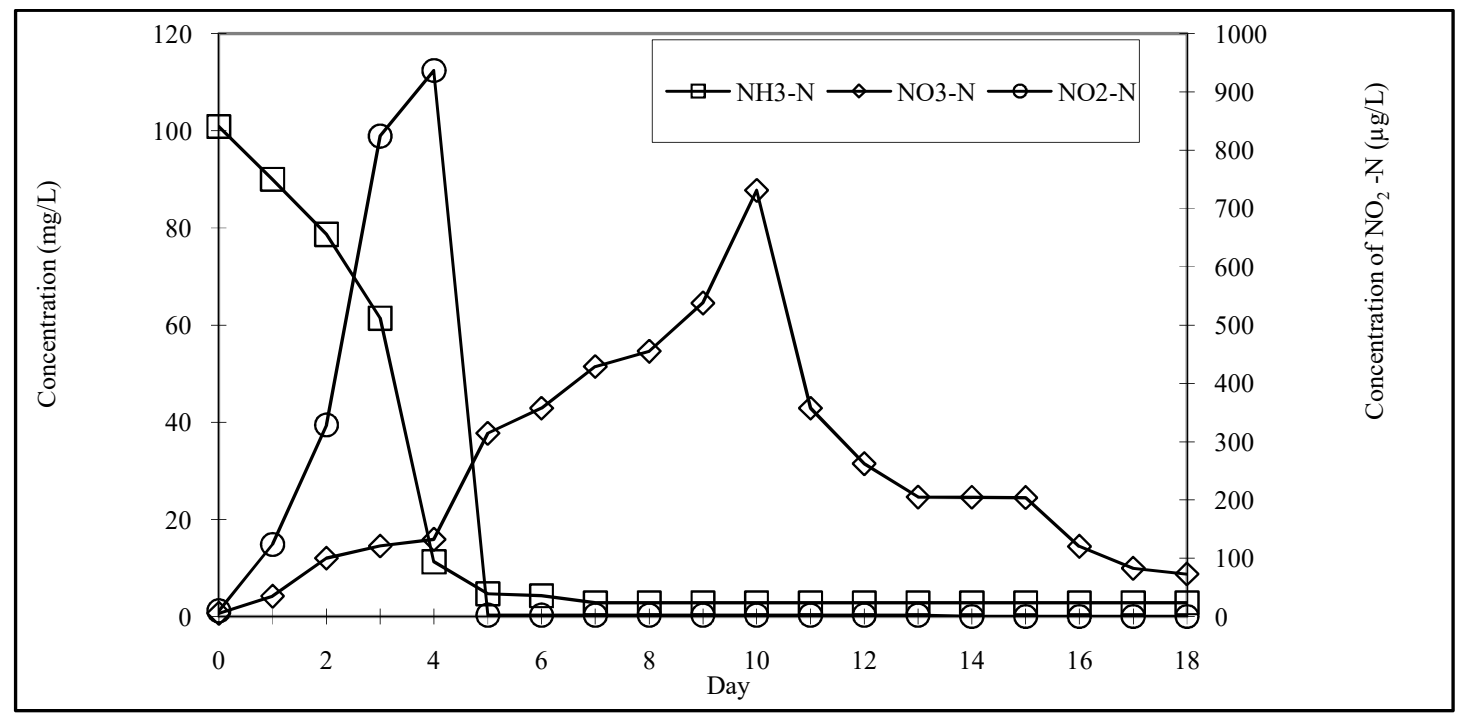

Fig.3D. The effect of $100 \mathrm{mg} / \mathrm{L}$ on nitrification in batch reactor experiments using the $\mathrm{K} 2$

AnoxKaldnes bio-filter

The $\mathrm{AOB}$ and $\mathrm{NOB}$ are thought to exist in the attached growth batch culture on the $\mathrm{K} 2$ AnoxKaldnes bio-filter. The nitrite-nitrogen does not accumulate in large concentrations under stable conditions because the maximum growth rate of the NOB is significantly higher than that of the AOB. As a result, the growth rate of AOB generally controls the overall rate of nitrification [10, 12]. This can be observed in Fig. 2 and Fig. 3, as all the nitrite-nitrogen concentrations achieved maximum values at intermediate incubation periods before the levels declined sharply as nitrate-nitrogen built up. In the nitrification process, the nitrite-nitrogen 
oxidation occurs faster than the ammonia-nitrogen oxidation; therefore, the nitrite-nitrogen rarely increases in the environment. This condition is very likely due to a minimum substrate concentration and the relatively high substrate consumption rate of nitrite oxidizers $[10,13]$.

A low dissolved oxygen concentration could affect the specific growth of AOB and NOB, depending on the saturation constant [14-15]. The population structure of nitrifiers changes when the concentration of dissolved oxygen is low. This condition could affect the nitrite-nitrogen accumulation rate [16]. By providing a high level of dissolved oxygen in the batch culture system, i.e. above $6 \mathrm{mg} / \mathrm{L}$, this should increase the population of nitrifiers such that the complete process of nitrification can be achieved [10].

The immobilized system adapted in the batch culture also contributed to a high density of nitrifiers. The nitrifiers can easily attach to the support media and the large surface area provided by the media increases the growth of the nitrifying bacteria. Further, the reactor volume in the immobilized reactor with a moving suspended carrier is totally mixed with dissolved oxygen, so new bacteria can increasingly occupy the surface area [5]. Consequently, there is no dead or unused space in the reactor system, so the reactor can function at a full capacity. In addition to that, the immobilized system has a small head loss and there is no need to recycle the biomass or sludge back into the system due to the high density of nitrifying bacteria that can be grown on the support media [17].

Fig. 4A shows a comparison of ammonia-nitrogen at different concentrations between $5 \mathrm{mg} / \mathrm{L}$ and $100 \mathrm{mg} / \mathrm{L}$ for a specific incubation period. The rate of ammonia-nitrogen removal was directly related to the initial concentration of ammonia-nitrogen. In all cases, the ammonia-nitrogen level reduced from $<2 \mathrm{mg} / \mathrm{L}$ to undetectable levels. At low concentrations, the ammonia-nitrogen was generally reduced in less than a week, while at high concentrations it took up to two weeks of incubation. The results indicated that an enhanced rate of ammonia oxidation was proportionate to the length of time needed for the nitrifying bacteria to consume the ammonia-nitrogen.

However, in response to the changes of the ammonia-nitrogen concentration introduced in the batch culture system, a long incubation time was needed for the nitrifying bacteria to consume high concentrations of ammonia-nitrogen. On the other hand, the experimental observations showed that with an initial concentration of $100 \mathrm{mg} / \mathrm{L}$ ammonia-nitrogen, the nitrifying 
bacteria could utilize the ammonia-nitrogen in one week's time. The incubation time for nitrifying bacteria with $100 \mathrm{mg} / \mathrm{L}$ ammonia-nitrogen was shorter compared to the other initial concentrations of the ammonia-nitrogen. This situation could be explained that the enrichment culture of the nitrifying bacteria was previously grown with an ammonia-nitrogen concentration of $100 \mathrm{mg} / \mathrm{L}$ [1]. Under these conditions, the nitrifying bacteria were already adapted to this ammonia-nitrogen concentration $(100 \mathrm{mg} / \mathrm{L})$, so these bacteria could assimilate ammonia-nitrogen faster compared to the conditions with different ammonia-nitrogen concentrations.

The ammonia-nitrogen (NH3-N) removal rate (mg/L.day) was calculated according to the geometric average calculation with respect to time:

$$
\begin{aligned}
& \mathrm{NH}_{3}-\mathrm{N} \text { removal rate }\left(\frac{m g}{L . d a y}\right)= \\
& \sum\left(\left(\text { Initial of } \mathrm{NH}_{3}-\mathrm{N}\right)-\left(\mathrm{NH}_{3}-N \text { remain }\right)\right)\left(\frac{m g}{L}\right)
\end{aligned}
$$

\section{Sums of days}

The percentage of the ammonia-nitrogen being removed with respect to time was calculated using the following equation:

$0 / 0 \mathrm{NH}_{3}-\mathrm{N}$ removal rate $=$

$\frac{\mathrm{NH}_{3}-\mathrm{N} \text { removal rate }\left(\frac{m g}{\text { L.day }}\right)}{\text { The highest value of } \mathrm{NH}_{3}-\mathrm{N} \text { removal rate }\left(\frac{m g}{\text { L.day }}\right)} \times 100$

Fig. 4B shows the removal rate of ammonia-nitrogen that was calculated according to the percentage of maximum removal of the ammonia-nitrogen by Equation (1) and Equation (2). For all investigated concentrations, the removal rates of ammonia-nitrogen increased steadily with the highest removal rate at $100 \mathrm{mg} / \mathrm{L}$. This shows that the nitrifying bacteria were capable of nitrifying the ammonia-nitrogen up to a concentration of $100 \mathrm{mg} / \mathrm{L}$ in the batch reactor with an attached growth system on the K2 AnoxKaldnes bio-filter.

The graphs in Fig. 4A and 4B were used to obtain data to determine the results in Fig. 5. A further explanation of the ammonia-nitrogen removal rate versus substrate concentrations 
(ammonia-nitrogen concentrations of $5 \mathrm{mg} / \mathrm{L}$ to $100 \mathrm{mg} / \mathrm{L}$ ) is illustrated in Fig. 5.

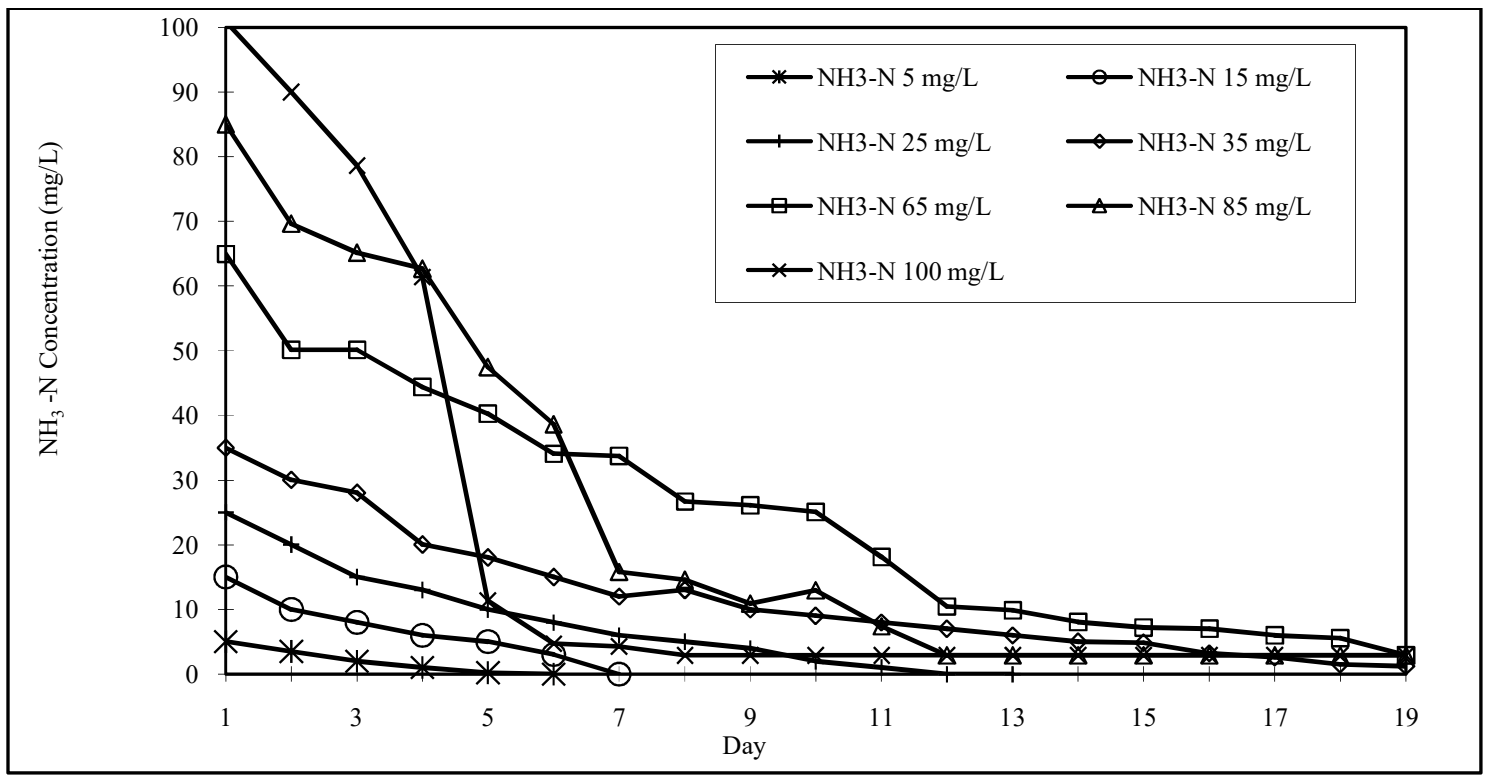

Fig.4A. The effect of ammonia-nitrogen concentrations in the K2 AnoxKaldnes bio-filter

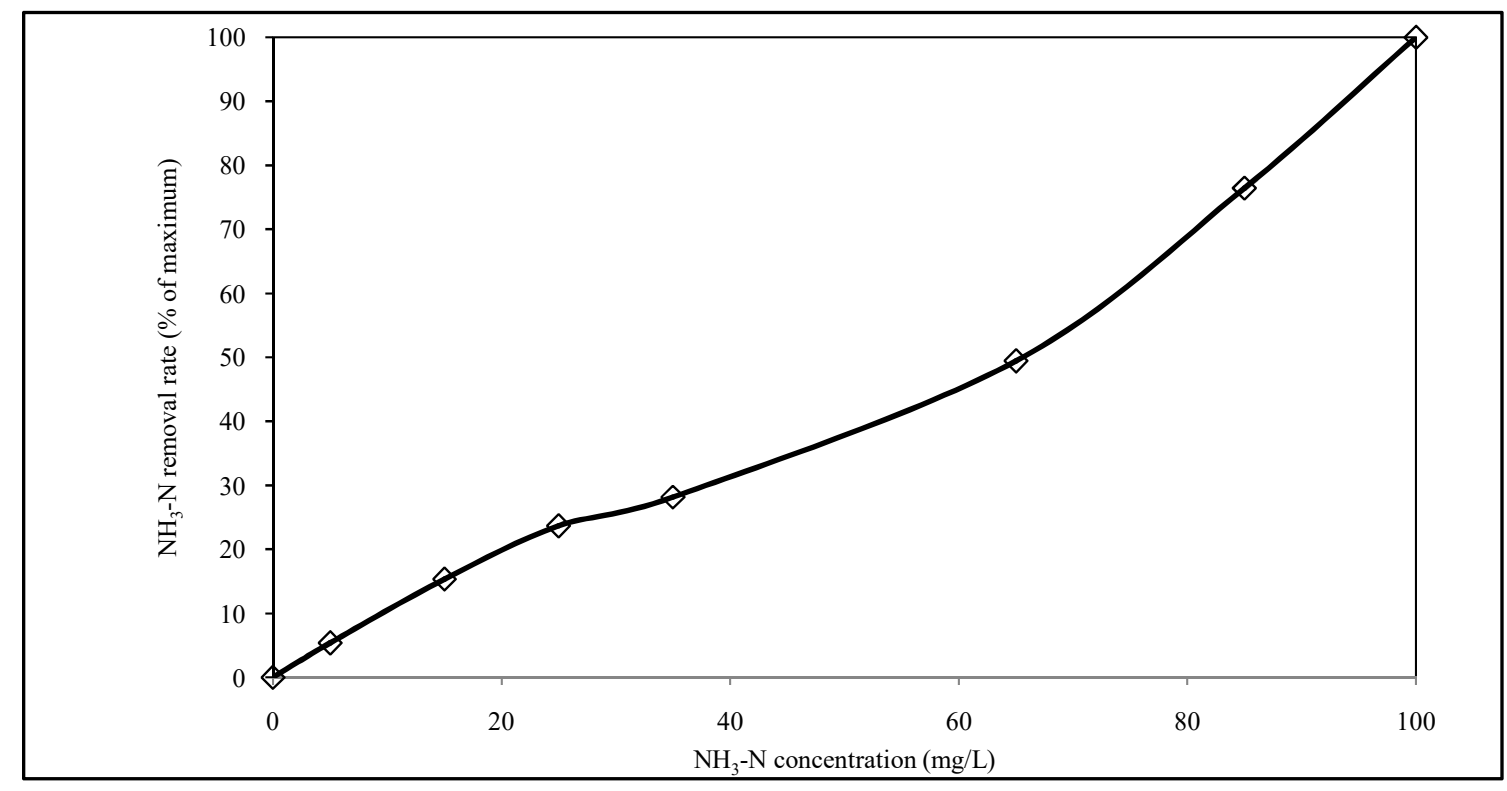

Fig.4B. The removal rate of ammonia-nitrogen vs. the ammonia-nitrogen concentration by Equation (1) and Equation (2)

The rate of ammonia-nitrogen removal is shown to follow the Michaelis-Menten kinetics by replotting the results on a double-reciprocal plot [18] (Fig. 5). The derivation of the double-reciprocal plot [18] is shown in the following equation: 


$$
\begin{gathered}
v=\frac{v_{\max } S}{K_{S}+S} \\
\frac{1}{v}=\frac{K_{S}+S}{v_{\max }+S}=\frac{K_{S}}{v_{\max }} \frac{1}{S}+\frac{1}{v_{\max }}
\end{gathered}
$$

where $\mathrm{V}=$ reaction rate, $\mathrm{Vmax}=$ maximum rate, $\mathrm{Ks}=$ Michaelis-Menten half saturation constant and $\mathrm{S}=$ substrate concentration.

The value used to plot the $\mathrm{x}$-axis is $1 / \mathrm{S}$ and that for the $\mathrm{y}$-axis is $1 / \mathrm{v}$ in a double-reciprocal plot [18]. The experimental results of the double-reciprocal plot showed the effect of the substrate concentration on the ammonia-nitrogen removal rate (nitrification process). Fig. 5 shows that the obtained maximum rate, Vmax and half saturation constant, Ks are $76.92 \mathrm{mg}$ NH3-N/L.day and $49 \mathrm{mg}$ NH3-N/L respectively.

The results of the double-reciprocal plot [18] in Fig. 5 were then fitted to the best linear equation to determine the maximum rate, Vmax and the half saturation constant, Ks. However, the graph of the double-reciprocal plot in Fig. 5 tended to curve in the beginning of the plot. Yet, the results plotted is important to obtain the optimum value for the calculation of the intercept for the maximum rate, Vmax and the slope to verify the half saturation constant, Ks. Data points restricted to the lower and upper portions of the double-reciprocal plot [18] gave the half saturation constant, Ks. In spite of that, to obtain a high substrate removal rate, the Ks value has to be low. The experiment showed that the half saturation constant, Ks, was very high with a value of $49 \mathrm{mg} \mathrm{NH3-N/L}$.

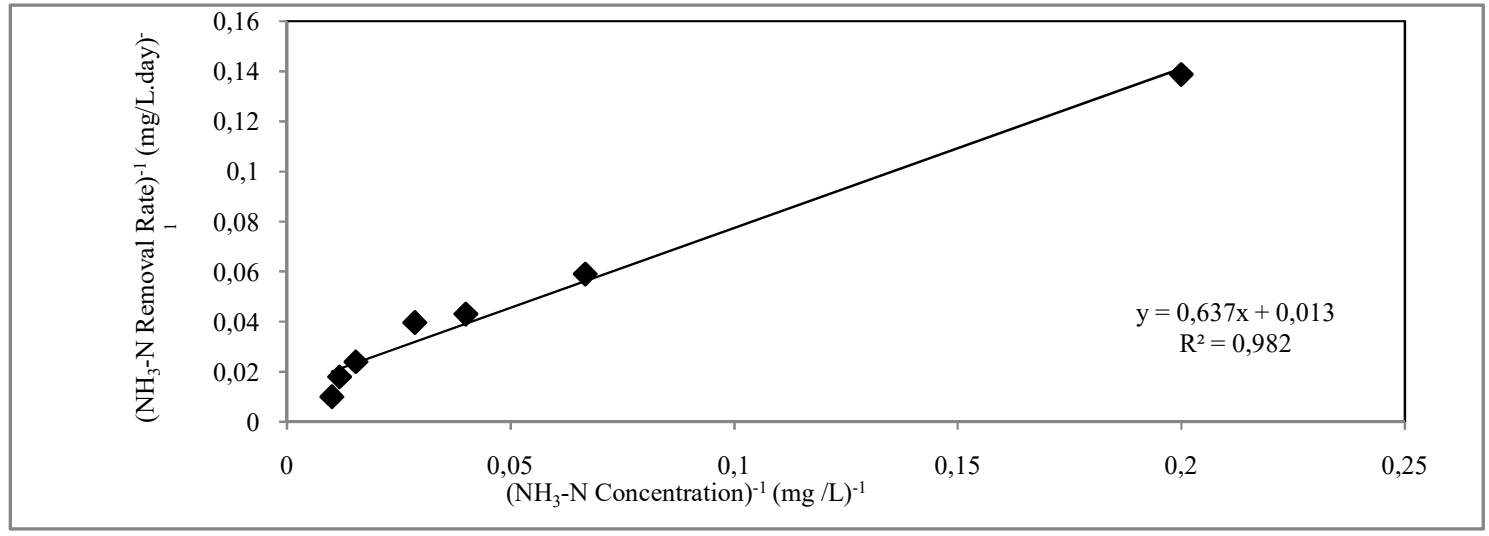

Fig.5. A double-reciprocal plot showing the effect of the substrate concentration on the ammonia-nitrogen removal rate (nitrification process) 
The inhibition of nitrification in nitrifying bacteria in this experimental investigation was high compared to other reported values obtained by other studies. The value of the half saturation constant for the two-step process of $\mathrm{AOB}$ and $\mathrm{NOB}$ in aerobic nitrifying granules was found to be $9.1 \mathrm{mg} \mathrm{NH3-N/L}$. this low value was achieved using granulation of nitrifying sludge in a sequencing batch reactor [19]. The nitrifying granule-based sequencing batch reactor is a very complex biological system with numerous internal interactions among process variables and sludge characteristics. Further, the biological processes in the granules are governed by the concentration gradients of oxygen and diverse substrates and these parameters greatly influence the overall performance of the system $[5,20]$.

In the activated sludge model proposed by [21] the half saturation constant, Ks had a value of $0.07 \mathrm{mg} \mathrm{NH3-N/L}$. This value is lower compared to the investigation done by [19] for the nitrifying granular system. This half saturation constant was obtained regardless of the model verification approach used with the activated sludge [21]. Other studies done on the nitrification kinetics of activated sludge in a biofilm system using a mathematical approach provided a Ks of $0.27 \mathrm{mg} \mathrm{NH3-N/L}$. However, this activated sludge-biofilm reactor was operated at a high temperature $(35+2 \mathrm{oC})$ with a low $\mathrm{pH}$ which was between 4.3 to 4.5 and with the biomass recycling back into the system. This was a continuous reactor with ammonia-nitrogen feeding in the range of 16 to $17 \mathrm{mg} \mathrm{NH3-N/L} \mathrm{[22].}$

Research was performed by [23] using a high ammonia-nitrogen concentration with an initial amount of $100 \mathrm{mg} \mathrm{NH3-N/L} \mathrm{in} \mathrm{a} \mathrm{fluidized} \mathrm{bed} \mathrm{reactor} \mathrm{system.} \mathrm{A} \mathrm{range} \mathrm{of} 300$ to $1000 \mathrm{mg}$ NH3-N/L were prepared consecutively and stirred in a tank reactor system, and the half saturation constant value, Ks, was calculated to be $540 \mathrm{mg} \mathrm{NH3-N/L}$. To compare, the saturation constant obtained by [23] was much higher than what found in the present study. So, did several other studies on activated sludge enrichment culture obtaining the Ks in the range of 0.3 to $0.7 \mathrm{~g} \mathrm{NH} 4-\mathrm{N} / \mathrm{L}$ at a temperature of $20^{\circ} \mathrm{C}$ [6].

There is considerable variation in the Ks values of the nitrifying bacteria, and there is no clear correlation among the type of culture of the nitrifying bacteria, the reactor system used or the dissolved oxygen, $\mathrm{pH}$ and temperature. In spite of that, these factors do contribute to the different of half saturation constant values [24].

However, in this study, a possible reason for the high measured value of the half saturation constant, Ks that as obtained was is due to the enrichment culture. The enrichment culture of the nitrifying bacteria was maintained with a non-limiting supply of ammonia-nitrogen at an initial level of $100 \mathrm{mg} / \mathrm{L}$ [1]. Hence, the efficiency of the mechanism to consume the ammonia-nitrogen by nitrifying bacteria in the reactor may have been reduced. Since these 
cultures were not permitted time to acclimatise to the experimental ammonia-nitrogen concentrations, the half saturation constant in this experimental study was high.

The result showed that the use of an immobilized system with the K2 AnoxKaldnes bio-filter could retain a high density of nitrifying bacteria to perform the ammonia oxidation by converting the ammonia-nitrogen to nitrite-nitrogen and nitrate-nitrogen. This microbial community of nitrifying bacteria was able to adapt to the changing ammonia-nitrogen levels while maintaining the nitrification activity. In the same light, as there is possibility of other types of bacteria present in the sample effluent, the observed growth constants in this experiment may have been shown by a mixed population of AOB and NOB.

\section{CONCLUSION}

It can be concluded that the AOB and NOB in the present study's batch culture reactor were tolerant to ammonia-nitrogen concentrations between $5 \mathrm{mg} / \mathrm{L}$ and $100 \mathrm{mg} / \mathrm{L}$. In the presence of an optimum amount of dissolved oxygen, temperature and $\mathrm{pH}$ in the given environment, the nitrifying organisms could survive and attach themselves to the immobilized suspended carrier system.

\section{ACKNOWLEDGEMENTS}

The authors would like to thank the Government of Malaysia and UniversitiTeknologi MARA, Shah Alam, Selangor for funding the research.

\section{REFERENCES}

[1] Kasmuri N, Lovitt R W, Omar M. Reducing ammonia-nitrogen by bio-filters. In 5th International Technical Conference Sabah, 2016, pp. 545-551

[2] Zhou S, Huang T, Ngo HH, Zhang H, Liu F, Zeng M, Shi J, Qiu X. Nitrogen removal characteristics of indigenous aerobic denitrifiers and changes in the microbial community of a reservoir enclosure system via in situ oxygen enhancement using water lifting and aeration technology. Bioresource Technology, 2016, 214:63-73

[3] Guthrie R, Duncan W, Owen R. UK environmental standards and conditions (phase

1).Edinburgh: UK Technical Advisory Group on the Water Framework Directive, 2008 
[4] Qu X, Alvarez PJ, Li Q. Applications of nanotechnology in water and wastewater treatment. Water Research, 2013, 47(12):3931-3946

[5] Liu C, Liu J, Li J, He H, Peng S, Li C, Chen Y. Removal of $\mathrm{H}_{2} \mathrm{~S}$ by co-immobilized bacteria and fungi biocatalysts in a bio-trickling filter. Process Safety and Environmental Protection, 2013, 91(1):145-152

[6] Henze M., Harremoes P., la Cour Jansen J., Arvin E. Wastewater treatment: Biological and chemical processes. Berlin: Springer Science and Business Media, 2001

[7] Shuler M., Kargi F. Bioprocess engineering basic concepts. New Jersey: Prentice Hall, 2014

[8] Kasmuri N. The removal of ammonia-nitrogen and degradation of 17alpha-ethynylestradiaol and mestranol using PFBR and MBBR. PhD thesis, Wales: Swansea University, 2014

[9] Liu T, Quan X, Li D. Evaluations of biofilm thickness and dissolved oxygen on single stage anammox process in an up-flow biological aerated filter. Biochemical Engineering Journal, 2017, 119:20-26

[10]Ge S, Wang S, Yang X, Qiu S, Li B, Peng Y. Detection of nitrifiers and evaluation of partial nitrification for wastewater treatment: A review. Chemosphere, 2015, 140:85-98

[11]Water Environmental Federation and American Public Health Association. Standard methods for the examination of water and wastewater. Washington DC: American Public Health Association, 2005

[12]Henze M. Biological wastewater treatment: Principles, modelling and design.London: International Water Association (IWA) Publishing, 2008

[13]Rittmann B., McCarty P. Environmental biotechnology: Principles and application.Noida: Tata McGraw-Hill Education, 2012

[14]Zafarzadeh A, Bina B, Nikaeen M, Attar HM, Nejad MH. Performance of moving bed biofilm reactors for biological nitrogen compounds removal from wastewater by partial nitrification-denitrification process. Iranian Journal of Environmental Health Science and Engineering, 2010, 7(4):353-364

[15]Daims H, Lücker S, Wagner M. A new perspective on microbes formerly known as nitrite-oxidizing bacteria. Trends in Microbiology, 2016, 24(9):699-712 
[16]Park H, Noguera D. Evaluating the effect of dissolved oxygen on ammonia- oxidizing bacterial communities in activated sludge. Water Research, 2004, 38(14-15):3275-3286

[17]Xiao L, Rodgers M, Mulqueen J. Organic carbon and nitrogen removal from a strong wastewater using a denitrifying suspended growth reactor and a horizontal-flow biofilm reactor. Bioresource Technology, 2007, 98(4):739-744

[18]Lineweaver H, Burk D. The determination of enzyme dissociation constants. Journal of American Chemical Society, 1934, 56(3):658-666

[19]Fang F, Ni B L, Sheng G, YuH. Kinetic analysis on the two-step processes of AOB and NOB in aerobic nitrifying granules. Applied Microbiology and Biotechnology, 2009, 83(6):1159-1169

[20] $\mathrm{Su} \mathrm{K}, \mathrm{Yu} \mathrm{H}$. A Generalized model for aerobic granule-based sequencing batch reactor: Model development. Environmental Science Technology,2006, 40(15):4703-4708

[21]Henze M. Activated sludge model no. 3. Scientific and technical report no 9: Activated sludge models ASM1, ASM2, ASM2d and ASM3. IWA Task Group on Mathematical Modeling for Design and Operation of Biological Wastewater Treatment,London: International Water Association (IWA) Publishing, 2000

[22]Thalla A, Bhargava R, Kumar P. Nitrification kinetics of activated sludge-biofilm system: A mathematical model. Bioresource Technology, 2010, 101(15):5827-5835

[23]Wiesmann U. Biological nitrogen removal from waste water. Advance Biochemical Engineering, 1994, 51:113-154

[24]Wiesmann U., Choi I. S., Dombrowski E. M. Fundamentals of biological wastewater treatment. New Jersey: John Wiley and Sons, 2007

\section{How to cite this article:}

Kasmuri N, Lovitt R W and Omar M. Consumption of Ammonia-nitrogen by AOB in Immobilized Batch Culture. J. Fundam. Appl. Sci., 2017, 9(6S), 257-272. 